\title{
Spatial and temporal variations of trace element distribution in soils and street dust of an industrial town in NW Spain: 15 years of study
}

\author{
A. Ordóñez ${ }^{\text {a,* }}$, R. Álvarez ${ }^{\text {a }}$, E. De Miguel ${ }^{\text {b }}$, S. Charlesworth ${ }^{c}$ \\ a Dep. Explotación y Prospecciôn de Minas, University of Oviedo, Escuela de Ingeniería de Minas, Energía y Materiales, c/Independencia, 13, 33004 Oviedo, Asturias, Spain \\ bnvironmental Geochemistry Research and Engineering Laboratory, Universidad Politécnica de Madrid, Spain \\ ${ }^{c}$ Centre for Agroecology, Water and Resilience, Coventry University, United Kingdom
}

\begin{abstract}
A B S T R A C T
Extensive spatial and temporal surveys, over 15 years, have been conducted in soil in urban parks and street dusts in one of the most polluted cities in western Europe, Avilés (NW Spain). The first survey was carried out in 1996, and since then monitoring has been undertaken every five years. Whilst the sampling site is a relatively small town, industrial activities (mainly the steel industry and $\mathrm{Zn}$ and Al metallurgy) and other less significant urban sources, such as traffic, strongly affect the load of heavy metals in the urban aerosol. Elemental tracers have been used to characterise the influence of these sources on the composition of soil and dust. Although PM $_{10}$ has decreased over these years as a result of environmental measures undertaken in the city, some of the "industrial" elements still remain in concentrations of concern for example, up to $4.6 \%$ and $0.5 \%$ of $\mathrm{Zn}$ in dust and soil, respectively. Spatial trends in metals such as $\mathrm{Zn}$ and $\mathrm{Cd}$ clearly reflect sources from the processing industries. The concentrations of these elements across Europe have reduced over time, however the most recent results from Avilés revealed an upward trend in concentration for $\mathrm{Zn}, \mathrm{Cd}, \mathrm{Hg}$ and As. A risk assessment of the soil highlighted As as an element of concern since its cancer risk in adults was more than double the value above which regulatory agencies deem it to be unacceptable. If children were considered to be the receptors, then the risk nearly doubles from this element.
\end{abstract}

\section{Introduction}

The negative effects of urbanization and industrialisation on the urban environment are well known (Sancini et al., 2011; Wang et al., 2012), due to the many geochemical studies of street dusts, road deposits and soils that have been undertaken (e.g. Charlesworth et al., 2003, 2011; De Miguel et al., 2007; Loredo et al., 2003; Tositti et al., 2014). These studies found that one of the most important heavy metal sources in urban environments is vehicle emissions. Whilst the gradual shift from leaded to unleaded petrol has significantly reduced vehicular emissions of this element, its persistence in the urban environment has been noted by authors such as Charlesworth et al. (2003)

\footnotetext{
* Corresponding author.

E-mail addresses: aoalonso@uniovi.es (A. Ordóñez), eduardo.demiguel@upm.es (E. De Miguel), apx119@coventry.ac.uk (S. Charlesworth).
}

and De Miguel et al. (1997), particularly near heavily trafficked areas. Traffic also contributes significant amounts of $\mathrm{Zn}, \mathrm{Cu}, \mathrm{Ba}, \mathrm{Cd}$ and $\mathrm{Ni}$ (Charlesworth et al., 2011).

However, the urban environment is exposed to varying concentrations of heavy metals from other anthropogenic sources such as fossil fuel combustion, mining, metallurgical and other industrial activities, as well as from natural geochemical processes, e.g. the resuspension of soil particles. Industrial sources of pollution are obviously specifically site related depending on the activity. The spatial distribution of pollutants in urban areas largely reflects the impact of current and past industrial activities, as well as traffic movements (Zierock, 1994). Due to rapid urbanization and scarcity of land, most of the parks and recreational areas in cities are often located close to major roads or industrial areas, where they are subject to many potential pollution sources (Li and Liu, 2001). The typology and density of industries, together with local factors such as weather conditions and wind patterns cause 
considerable variation in the concentrations of heavy metals found in urban environments, as was found in Ordóñez et al. (2003). This latter study was carried out in an industrial city in Northern Spain: Avilés, and was based on the collection and analysis of street dusts and soils. The study found that there were concerning levels of elements such as $\mathrm{Zn}, \mathrm{Cd}, \mathrm{Hg}$ and $\mathrm{Pb}$ in the street dusts related to industrial activities and exhaust emissions, with similar distributions but lower concentrations in the soil samples. Such metal concentrations have the potential to have significantly negative impacts on the health of those living in such industrialised cities.

Trends with time across Europe appear to reflect the declining economic situation, with metals exhibiting a general decline in their deposition (sampled in mosses across Europe) in recent decades. For example, between 1990 and 2005, the average concentrations of As, $\mathrm{Cd}, \mathrm{Cr}, \mathrm{Cu}, \mathrm{Fe}, \mathrm{Hg}, \mathrm{Ni}, \mathrm{Pb}, \mathrm{V}$ and $\mathrm{Zn}$ declined by values ranging from $11 \%(\mathrm{Cu})$ to $77 \%(\mathrm{~Pb})$ (Harmens et al., 2013). This particular study reported on concentrations of a variety of metals as well as nitrogen from 3 regions in northern Spain (La Rioja and Navarra in the NE, and Galicia to the NW) but not Asturias.

Many studies on street dust have focused on elemental concentrations and source identification (Charlesworth et al., 2011; De Miguel et al., 1997; Ferguson and Kim, 1991). Heavy metals in urbanized areas can accumulate on topsoil from atmospheric deposition by sedimentation, impaction and interception (Sezgin et al., 2004), with lengthy persistence (Alloway, 1990; Kelly et al., 1996). Inhalation of suspended particles and ingestion of dust particles and soils (especially in the case of children) are among the possible routes through which people can be exposed to these elevated levels of trace elements. If children and the elderly are exposed to an environment with high metal contamination, their health may be affected (Charlesworth et al., 2011; Li and Liu, 2001). Consequently, the geochemical investigation of pollution in soils and street dust particles is an important contribution to the characterisation of the urban environment and associated potential health risks.

The aim of this research was to carry out a comprehensive urban geochemical study focussing on urban parks and roadside dusts in a traditionally industrial Spanish town. It assesses, both spatially and temporally, heavy metal contamination over a 15 year period (1996-2011), investigating possible sources of the metals and also the potential implications of elevated levels on human health.

\section{Area of study}

Avilés is a city located on the coast of Asturias, NW Spain (Fig. 1). It used to be a markedly industrial area, including the steel industry and non-ferrous metal production (mainly $\mathrm{Zn}$ and $\mathrm{Al}$ ), glass production, fertilizer and manufacturing, but some of these activities have declined over the last few years. Factories related to $\mathrm{Zn}, \mathrm{Al}$ and steel production and processing are located to the N, NE and $\mathrm{E}$ of the city, respectively. Due to industrial growth in the city the population quadrupled from 1950 to 1970 , but recently decreased, currently standing at 83,000 inhabitants (SADEI, 2014).

Environmental guideline values for several substances have been dramatically exceeded in the past. For example, during December 1979 , the level of total suspended solids was 300 times the maximum allowed value. This lead to Avilés being declared a Polluted Atmosphere Area in January 1981, the most polluted city in Spain, and one of the most polluted European cities (Gobierno del Principado de Asturias, 2014). Suspended particulate matter was of particular concern, leading to high incidences of asthma. Industrial restructuring began in 1990: several factories closed or introduced more conservative environmental measures and monitoring plans. Also, a series of actions undertaken by

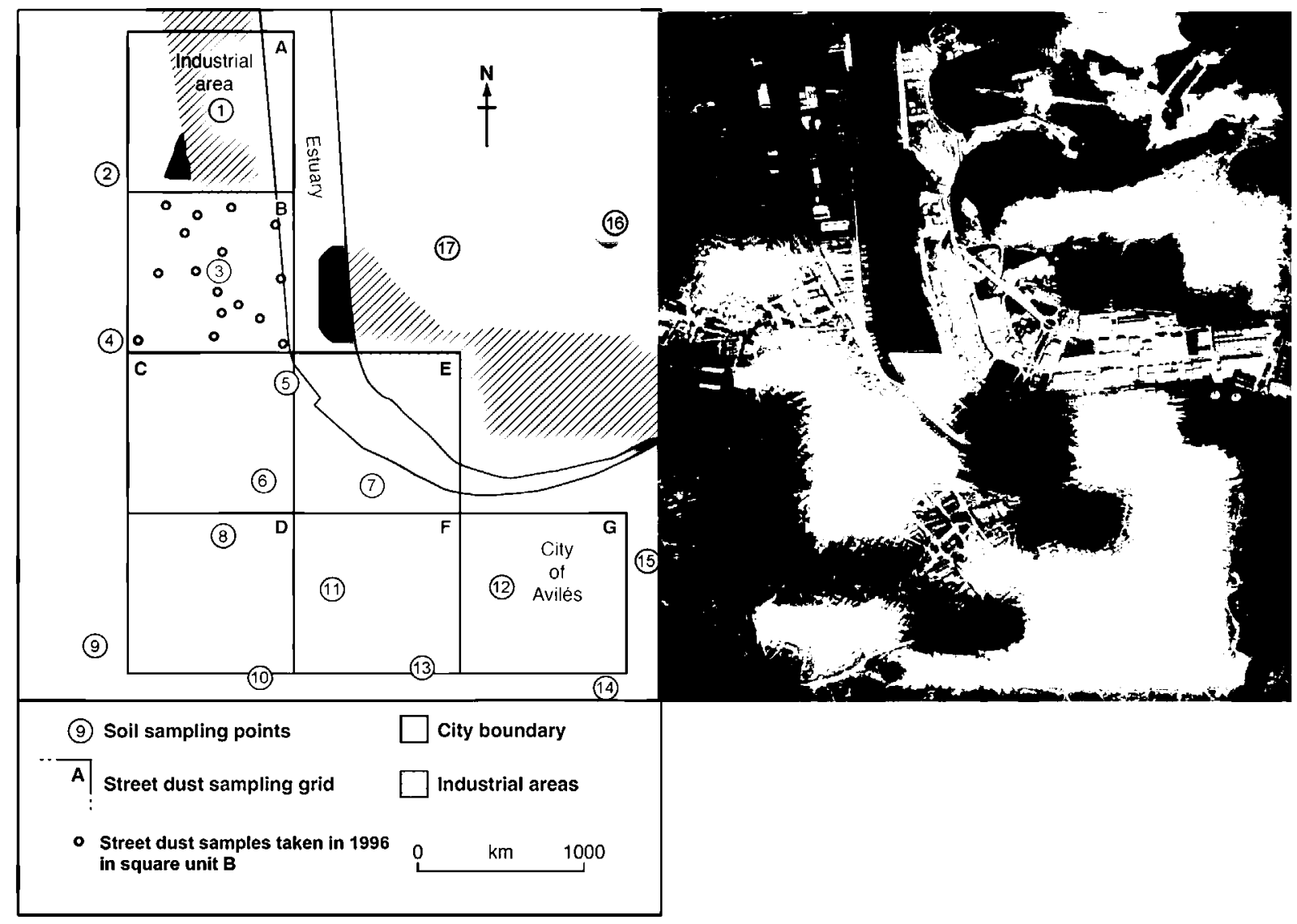

Fig. 1. Study area: soil sampling points and street dust sampling grid. 
local authorities over the last 30 years have helped to meet air quality objectives, resulting in regeneration of the urban environment. Currently, only one monitoring station (located in the $\mathrm{N}$ of the city) revealed that the allowed levels of $\mathrm{PM}_{10}$ had been exceeded, due to its proximity to an area of storage and handling of bulk ore from the port. Analysis of the particles retained on the filter from that monitoring station had high concentrations of $\mathrm{Zn}$ and S (up to $90 \%$ ), but these were not found at the other stations (Gobierno del Principado de Asturias, 2014). Fig. 2 shows the general downward trend in average $P M_{10}$ values registered across the city's monitoring network during 1996-2013. The same figure shows the Industrial Production Index (IPI) of metal industries in Asturias which increased until recently, when it was affected by the economic crisis.

Major roads with high vehicular traffic density cross the city reach up to 20,000 light vehicles/day (Ordóñez et al., 2003); however, away from these major roads the rest of the city is rather quiet. $50 \%$ of the houses were built before 1960 and $81 \%$ before 1980 , with the built environment in total occupying an area of more than 5 million $\mathrm{m}^{2}$, which increases on average about $1.4 \%$ per year (SADEI, 2014).

The local bedrock geology consists mainly of clastic rocks (conglomerates), red clays, carbonates (limestones and dolostones) and marls of Mesozoic age (López and Flor, 2008), covered by recent deposits near the estuary, which has been partly filled up artificially. Consequently, the terrain is basically flat, with an elevation ranging from 0 to $140 \mathrm{~m}$ above sea level (SADEI, 2014).

According to the Agencia Estatal de Metereología, the climate is humid, with an average yearly precipitation over the last 45 years of $1100 \mathrm{~mm}$ (effective rainfall of $410 \mathrm{~mm}$ per year) and a mean temperature of $13{ }^{\circ} \mathrm{C}$. The wind direction is predominantly west (55\%), although wind velocities are generally low (average of $3-4 \mathrm{~m} \mathrm{~s}^{-1}$ ). The wind direction explains maximum $\mathrm{PM}_{10}$ values registered at some of the city's monitoring stations (Gobierno del Principado de Asturias, 2014).

\section{Methods}

Street dust, the particulate matter deposited onto urban roads and pavements, has high spatial variability, so it is essential to select the appropriate sampling design. Therefore, the urban area was divided into seven mapping squares of $1 \mathrm{~km}^{2}$ each, designated A to $\mathrm{G}$ (Fig. 1). Sixteen sampling points were randomly distributed in each mapping unit, yielding a total of 112 subsamples in both residential and industrial sectors. Sampling was always carried out one week after the last precipitation event. Sampling was performed using a small broom and a dustpan, collecting dust deposited mainly on the road, close to the pavement. The approximately $150 \mathrm{~g}$ of street dust collected at each

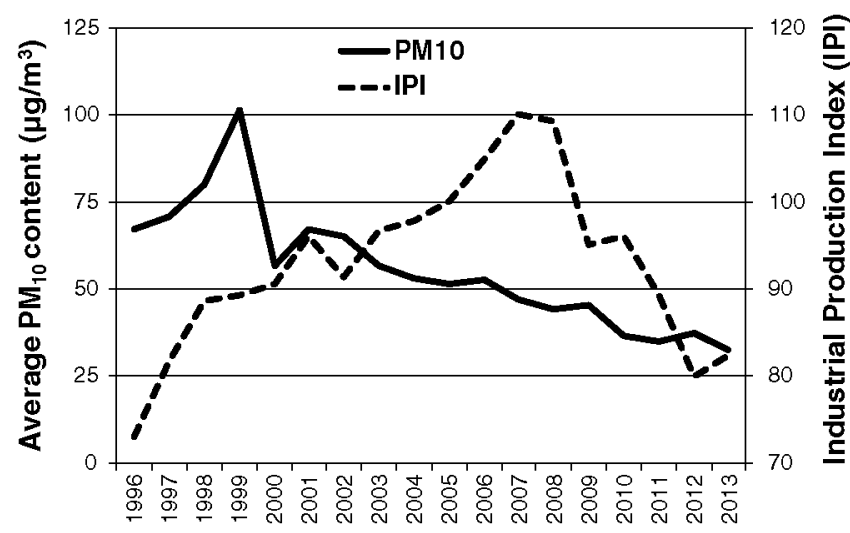

Fig. 2. Average $\mathrm{PM}_{10}$ content in Avilés and the Industrial Production Index of metal industries in Asturias (2005 referenced) from 1996-2013. sampling point was combined to represent one whole mapping unit. This sampling design was maintained in all four sampling campaigns, although the location of the 16 subsamples could not be maintained, due to the variability in dust deposition. As an example, the location of the 16 subsamples taken in unit B in the 1996 campaign is shown in Fig. 1. As detailed in Ordóñez et al. (2003), Visman methodology (Visman, 1947) was applied in order to evaluate precision in terms of estimating the sampling unit's mean value.

In urban soils it is not possible to apply a systematic sampling design as their location depends on there being open areas such as parks, yards, roads, roadsides, private gardens, and undeveloped land, from which to sample, and these are not evenly distributed across the city. Samples were collected from public parks and other green areas to cover the different districts of the city and assess possible influences from traffic or industry as a function of distance from their potential source. Sampling points were located at about $15 \mathrm{~m}$ from the nearest major road or street with high traffic density. Soils collected were not necessarily restricted to the urban area, unlike the street dust campaign, and therefore covered a larger area $\left(10 \mathrm{~km}^{2}\right)$ including soils surrounding the city. As far as the authors know, the areas where soils were collected are not fertilized and the potential contribution of compost to the trace element load was therefore considered negligible.

Soil samples were composites of five subsamples (of about $0.5 \mathrm{~kg}$ each), which were taken according to a cross pattern (centre and extremes), with $5 \mathrm{~m}$ distance between subsamples. These were taken using garden tools (a small pick to make a surface hole and a plastic shovel to collect the samples). In 1996, 40 samples in total were collected (Ordóñez et al., 2003), whereas in campaigns which followed, only 17 samples were taken from the same sites (designated nos. 1 to 17), chosen from the locations identified in 1996 (Fig. 1); these locations were selected as the most visited green spaces in the centre of the city, some associated with residential blocks and some with the city outskirts. In 1996 and 2006, samples were collected from the upper $15 \mathrm{~cm}$ of the soil profile, whereas in 2001 they were collected from the upper $25 \mathrm{~cm}$; in the last campaign (2011), samples were taken at both depths (15 and $25 \mathrm{~cm}$ ) every time in order to evaluate the vertical mobility of trace elements in the soil profile and how this translocation may affect the concentrations reported for different depths.

In order to avoid metal contamination, only plastic tools were used for dust and soil sampling. All the samples were kept in plastic bags and taken to the laboratory. After drying for $72 \mathrm{~h}$ at $45^{\circ} \mathrm{C}$, each sample was sieved through a $2 \mathrm{~mm}$ non-metallic mesh to remove large particles, and then carefully homogenised and sieved to obtain the $<147 \mu \mathrm{m}$ fraction (particles that can be easily resuspended). After reduction by repeated quartering, $0.5 \mathrm{~g}$ subsamples were digested using $3 \mathrm{ml}$ of $3: 1: 2 \mathrm{HCl}: \mathrm{HNO}_{3}: \mathrm{H}_{2} \mathrm{O}$ at $95{ }^{\circ} \mathrm{C}$ for $1 \mathrm{~h}$ and diluted to $10 \mathrm{ml}$ with water. Multielemental analyses of all samples from all campaigns were determined by ICP-MS at accredited ACME Analytical Laboratories, in Vancouver (Canada). Quality controls involved routine analyses of standards and duplicates. Approximately $5 \%$ of the samples were analysed as internal and external control samples; the variability was found to be $<10 \%$ for all elements analysed.

Descriptive statistics of the analytical data, as well as multivariate analysis techniques, i.e. Cluster Analysis, were performed to describe and interpret the results.

In order to identify metal-enriched particles and whether they had combined with other elements, two samples from the 2011 campaign (street dust from grid A and soil from superficial sample no. 16) were observed by means of scanning electron spectroscopy. SEM-EDAX studies were carried out at the Oviedo University facilities, using a JEOL $6610 \mathrm{LV}$ Scanning Electron Microscope ( $30 \mathrm{kV}, 3 \mathrm{~nm}$ of theoretical resolution) with a silicon-drift detector type X-max 50 (125 eV to $60 \mathrm{keV}$ ). Secondary electrons were used to obtain the images and backscattered electrons were used to identify particles with elements of high molecular weight. Elemental analyses were developed with an EDAX module. This technique enabled the characterisation of size, morphology, and 
Table 1

Descriptive statistics of the analytical data found in street dust from the four sampling campaigns ( $\mathrm{n}=7$ at each campaign).

\begin{tabular}{|c|c|c|c|c|c|c|c|c|c|c|c|c|c|c|c|c|c|c|c|c|}
\hline & \multicolumn{4}{|l|}{ Min. } & \multicolumn{4}{|l|}{ Max. } & \multicolumn{4}{|c|}{ Arith. mean } & \multicolumn{4}{|l|}{ Median } & \multicolumn{4}{|c|}{ Coef. variation } \\
\hline & 1996 & 2001 & 2006 & 2011 & 1996 & 2001 & 2006 & 2011 & 1996 & 2001 & 2006 & 2011 & 1996 & 2001 & 2006 & 2011 & 1996 & 2001 & 2006 & 2011 \\
\hline $\mathrm{Ag}\left(\mathrm{mg} \mathrm{kg}^{-1}\right)$ & 0.40 & 0.30 & 0.40 & 1.10 & 4.55 & 3.20 & 2.90 & 10.9 & 1.73 & 1.20 & 0.97 & 3.76 & 1.75 & 0.40 & 0.80 & 3.20 & 0.81 & 0.97 & 0.90 & 0.89 \\
\hline $\mathrm{Al}(\%)$ & 0.72 & 0.61 & 0.46 & 0.71 & 1.12 & 0.81 & 0.72 & 1.07 & 0.86 & 0.70 & 0.62 & 0.84 & 0.86 & 0.70 & 0.67 & 0.78 & 0.17 & 0.09 & 0.17 & 0.16 \\
\hline $\mathrm{As}(\mathrm{mg} \mathrm{kg}-1)$ & 11.0 & 10.9 & 9.70 & 16.4 & 26.0 & 29.8 & 29.4 & 110.1 & 18.2 & 18.7 & 22.1 & 37.6 & 18.0 & 18.8 & 24.0 & 28.7 & 0.30 & 0.32 & 0.33 & 0.86 \\
\hline $\mathrm{Ba}\left(\mathrm{mg} \mathrm{kg}^{-1}\right)$ & 244 & 303 & 248 & 185 & 489 & 446 & 407 & 640 & 369 & 386 & 326 & 400 & 375 & 378 & 327 & 405 & 0.21 & 0.14 & 0.19 & 0.38 \\
\hline $\mathrm{Ca}(\%)$ & 9.08 & 7.96 & 5.75 & 9.90 & 12.0 & 10.1 & 11.0 & 14.1 & 10.2 & 9.11 & 8.05 & 12.0 & 9.7 & 9.17 & 7.21 & 12.3 & 0.11 & 0.08 & 0.25 & 0.12 \\
\hline $\mathrm{Cd}\left(\mathrm{mg} \mathrm{kg}^{-1}\right)$ & 9.60 & 6.70 & 4.00 & 11.0 & 104 & 82.6 & 41.3 & 139 & 31.2 & 26.0 & 15.4 & 45.1 & 15.7 & 11.1 & 11.2 & 26.1 & 1.07 & 1.16 & 0.82 & 1.01 \\
\hline $\mathrm{Co}\left(\mathrm{mg} \mathrm{kg}^{-1}\right)$ & 5.00 & 3.4 & 3.7 & 6.4 & 11.50 & 8.9 & 6.5 & 19.2 & 7.36 & 5.44 & 5.24 & 10.9 & 6.50 & 4.70 & 5.20 & 10.7 & 0.33 & 0.36 & 0.17 & 0.41 \\
\hline $\mathrm{Cr}\left(\mathrm{mg} \mathrm{kg}^{-1}\right)$ & 32.0 & 46.2 & 29.0 & 57.0 & 54.5 & 73.4 & 67.0 & 214 & 42.4 & 55.7 & 50.6 & 109 & 44.5 & 55.2 & 52.0 & 102 & 0.20 & 0.16 & 0.25 & 0.49 \\
\hline $\mathrm{Cu}\left(\mathrm{mg} \mathrm{kg} \mathrm{g}^{-1}\right)$ & 104 & 159 & 102 & 167 & 374 & 222 & 319 & 966 & 203 & 189 & 212 & 370 & 171 & 189 & 189 & 265 & 0.51 & 0.12 & 0.38 & 0.75 \\
\hline $\mathrm{Fe}(\%)$ & 3.24 & 2.14 & 1.47 & 2.36 & 5.74 & 3.30 & 3.58 & 6.56 & 4.30 & 2.63 & 2.51 & 3.87 & 4.60 & 2.59 & 2.45 & 3.82 & 0.21 & 0.18 & 0.30 & 0.37 \\
\hline $\mathrm{Ga}(\mathrm{mg} \mathrm{kg}-1)$ & & 1.00 & 1.00 & 2.00 & & 3.00 & 2.00 & 6.00 & & 1.57 & 1.57 & 3.00 & & 1.00 & 2.00 & 3.00 & & 0.50 & 0.34 & 0.47 \\
\hline $\mathrm{Hg}\left(\mathrm{mg} \mathrm{kg}^{-1}\right)$ & 1.20 & 0.31 & 0.18 & 0.90 & 10.8 & 4.03 & 1.08 & 10.3 & 3.40 & 1.40 & 0.60 & 2.93 & 1.95 & 0.61 & 0.61 & 1.53 & 0.99 & 1.09 & 0.49 & 1.14 \\
\hline $\mathrm{K}(\%)$ & 0.09 & 0.07 & 0.06 & 0.10 & 0.24 & 0.18 & 0.17 & 0.18 & 0.14 & 0.11 & 0.11 & 0.13 & 0.15 & 0.09 & 0.10 & 0.13 & 0.33 & 0.38 & 0.32 & 0.21 \\
\hline $\mathrm{La}\left(\mathrm{mg} \mathrm{kg}^{-1}\right)$ & 8.0 & 9.0 & 6.0 & 8.0 & 11.5 & 31.0 & 8.0 & 11.0 & 10.4 & 16.4 & 7.57 & 9.14 & 11.0 & 11.0 & 8.00 & 9.00 & 0.13 & 0.57 & 0.10 & 0.12 \\
\hline $\mathrm{Mg}(\%)$ & 0.94 & 1.01 & 0.73 & 0.83 & 1.29 & 1.84 & 1.20 & 1.23 & 1.10 & 1.47 & 0.85 & 0.98 & 1.06 & 1.44 & 0.77 & 0.90 & 0.12 & 0.21 & 0.20 & 0.17 \\
\hline $\mathrm{Mn}\left(\mathrm{mg} \mathrm{kg}^{-1}\right)$ & 1194 & 1301 & 604 & 1074 & 3149 & 2415 & 1467 & 4761 & 1770 & 1793 & 1095 & 2522 & 1446 & 1766 & 1106 & 2362 & 0.41 & 0.21 & 0.24 & 0.56 \\
\hline Mo (mg kg-1) & 3.0 & 3.5 & 2.9 & 3.6 & 5.0 & 6.9 & 7.2 & 10.3 & 4.2 & 4.7 & 5.2 & 6.9 & 4.0 & 4.5 & 5.3 & 7.2 & 0.17 & 0.22 & 0.30 & 0.35 \\
\hline $\mathrm{Na}(\%)$ & 0.03 & 0.02 & 0.02 & 0.03 & 0.05 & 0.04 & 0.11 & 0.09 & 0.04 & 0.03 & 0.04 & 0.05 & 0.04 & 0.03 & 0.03 & 0.04 & 0.21 & 0.25 & 0.71 & 0.51 \\
\hline $\mathrm{Ni}\left(\mathrm{mg} \mathrm{kg}^{-1}\right)$ & 18.0 & 15.0 & 16.0 & 22.4 & 50.0 & 25.8 & 27.1 & 69.3 & 28.9 & 21.3 & 21.8 & 43.3 & 28.5 & 21.3 & 24.9 & 33.8 & 0.36 & 0.18 & 0.23 & 0.50 \\
\hline $\mathrm{P}(\%)$ & 0.04 & 0.05 & 0.07 & 0.06 & 0.23 & 0.32 & 0.13 & 0.28 & 0.11 & 0.13 & 0.10 & 0.14 & 0.07 & 0.08 & 0.08 & 0.12 & 0.69 & 0.78 & 0.24 & 0.48 \\
\hline $\mathrm{Pb}\left(\mathrm{mg} \mathrm{kg}^{-1}\right)$ & 330 & 162 & 157 & 208 & 964 & 919 & 705 & 1482 & 559 & 400 & 289 & 496 & 484 & 278 & 207 & 320 & 0.46 & 0.69 & 0.67 & 0.92 \\
\hline $\mathrm{Sb}\left(\mathrm{mg} \mathrm{kg}^{-1}\right)$ & 7.0 & 4.8 & 5.4 & 5.7 & 9.0 & 8.9 & 15 & 20 & 8.0 & 6.9 & 8.3 & 10.4 & 8.0 & 7.2 & 7.6 & 8.8 & 0.08 & 0.23 & 0.40 & 0.46 \\
\hline $\mathrm{Sr}\left(\mathrm{mg} \mathrm{kg}^{-1}\right)$ & 222 & 208 & 159 & 255 & 310 & 422 & 242 & 362 & 266 & 277 & 201 & 315 & 271 & 226 & 192 & 324 & 0.13 & 0.34 & 0.16 & 0.11 \\
\hline $\operatorname{Th}\left(\mathrm{mg} \mathrm{kg} \mathrm{kg}^{-1}\right)$ & 4.00 & 1.70 & 1.10 & 1.60 & 8.00 & 2.00 & 1.90 & 2.30 & 6.50 & 1.90 & 1.50 & 1.96 & 6.50 & 1.90 & 1.50 & 2.00 & 0.21 & 0.06 & 0.19 & 0.13 \\
\hline $\operatorname{Ti}(\%)$ & 0.02 & 0.02 & 0.01 & 0.02 & 0.03 & 0.03 & 0.02 & 0.04 & 0.02 & 0.02 & 0.02 & 0.03 & 0.02 & 0.02 & 0.02 & 0.03 & 0.21 & 0.12 & 0.19 & 0.31 \\
\hline $\mathrm{V}\left(\mathrm{mg} \mathrm{kg}^{-1}\right)$ & 25 & 22 & 18 & 29 & 35 & 29 & 28 & 76 & 28 & 26 & 23 & 44 & 28 & 25 & 22 & 39 & 0.12 & 0.11 & 0.15 & 0.36 \\
\hline$W\left(\mathrm{mg} \mathrm{kg}^{-1}\right)$ & $<2$ & 0.7 & 0.4 & 0.7 & 4.0 & 1.5 & 1.9 & 6.5 & 3.5 & 1.0 & 0.9 & 2.7 & 3.5 & 0.9 & 0.7 & 2.2 & 0.20 & 0.30 & 0.59 & 0.69 \\
\hline $\mathrm{Zn}\left(\mathrm{mg} \mathrm{kg}^{-1}\right)$ & 2422 & 1359 & 813 & 3015 & 23,400 & 10,966 & 3037 & 45,675 & 6904 & 4018 & 1833 & 12,036 & 3112 & 2091 & 1641 & 5682 & 1.09 & 0.95 & 0.41 & 1.27 \\
\hline
\end{tabular}



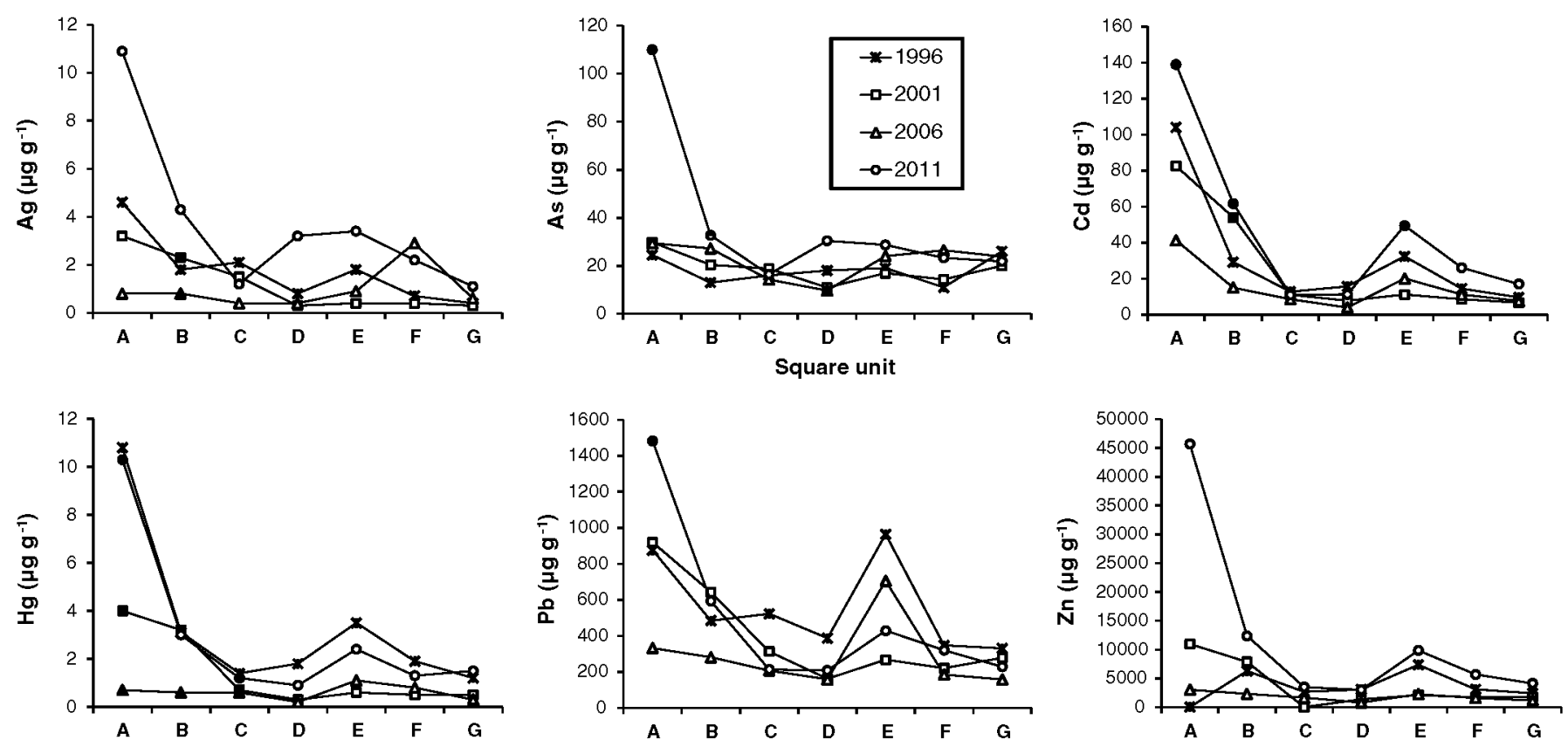

Fig. 3. Metal contents found in the square units sampled for street dust.

chemical composition of metal-bearing particles (Miler and Gosar, 2012, 2013, 2015).

The mineral composition of the same samples used for SEM was determined by X-ray Diffraction (XRD), utilising the powder method, and a Bruker D8 Discover diffractometer, working with $\mathrm{K}_{\alpha} \mathrm{Cu}$ radiation and an Ni filter. The applied voltage and anodic current were $45 \mathrm{kV}$ and $40 \mathrm{~mA}$, respectively.

The methodology used by Wang et al. (2012) when defining the concept of "urban environmental entropy" to investigate the effect of urbanization on the overlying atmosphere, was applied to this case. Urban growth is a necessary condition for the urban system to prevail but as it is irreversible, it may decrease the quality of the system. Entropy is a commonly used way to address urban sprawl; it must be kept within a range in which the system is sustainable. Environmental pollution generates excess entropy; the greater the entropy, the greater the effect on the environment (Cabral et al., 2013; Ouyang et al., 2008). The relationship between the development of urbanization and street dust quality in Avilés between 1996-2011 has therefore been studied through the determination of urban environmental entropy in the 7 square sampling units, based on statistical analysis of the main metals ( $\mathrm{Al}, \mathrm{Ba}, \mathrm{Fe}, \mathrm{Pb}$ and $\mathrm{Zn}$ ) present in the samples.

Lastly, the potential health effects on the urban population of the exposure to trace elements in dust and soil were derived from a risk assessment following the USEPA methodology. To characterise the systemic and carcinogenic risk, a Hazard Index (Eq. (1)) and a Cancer Risk (Eq. (2)), respectively, were determined. The chronic average daily dose (CADD) or concentration in air $\left(C_{\mathrm{air}}\right)$ was divided by the corresponding reference dose ( $R f D)$ or reference concentration ( $R f C$ ), and the lifetime average daily dose (LADD) or concentration in air was multiplied by the corresponding slope factor (SF) or unit risk (UR). Additivity of adverse health effects was assumed for mixtures of elements and multiple exposure routes.

$\mathrm{HI}=\sum_{i} \mathrm{HQ}_{\mathrm{i}} \quad \mathrm{HQ}=\frac{\mathrm{CADD}\left[\mathrm{C}_{\mathrm{air}}\right]}{\operatorname{RfD}[\mathrm{RfC}]}$

$\mathrm{RISK}=\sum_{i}$ RISK $_{\mathrm{i}} \quad$ RISK $_{\mathrm{i}}=\mathrm{LADD}\left[\mathrm{C}_{\mathrm{air}}\right] \cdot \mathrm{SF}[\mathrm{UR}]$
Chronic and lifetime average doses through ingestion, inhalation and absorption through the skin were calculated using USEPA's default exposure parameters for a residential scenario. Toxicity values were retrieved from the US Department of Energy's Risk Assessment Information System (USDoE, 2014), except the oral reference dose for $\mathrm{Pb}$, which was derived from the World Health Organization's Guidelines for Drinking Water Quality. Dermal toxicity values have been determined from oral values, multiplying reference doses and dividing slope factors by the corresponding gastrointestinal absorption factor. The concentration term used in the estimate of reasonable maximum exposure was the upper limit of the 95\% confidence interval for the arithmetic mean (calculated with ProUCL 5.0 software (USEPA, 2014)).

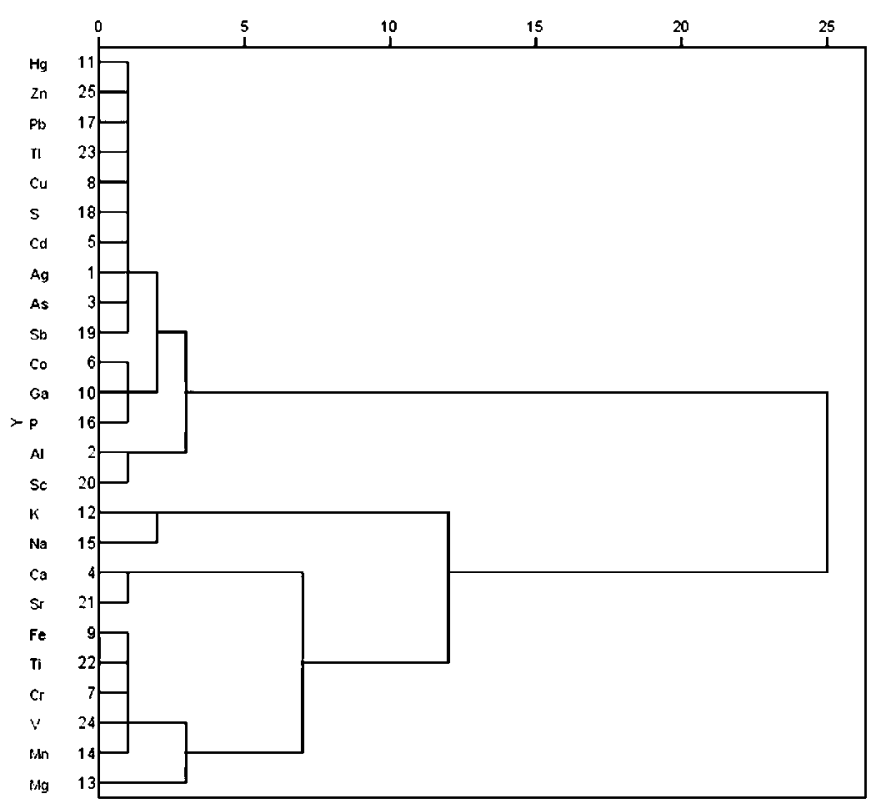

Fig. 4. Clustering of variables analysed for street dust in 2011 (Linkage method: Ward; squared Euclidian distance). 


\section{Results and discussion}

\subsection{Street dust}

A statistical summary of the analytical results of the 1996, 2001, 2006 and 2011 sampling campaigns is shown in Table 1 . The coefficient of variation (standard deviation/mean) is low for Ca, Mg, Sr, V, La and Th. The concentrations of these geogenic elements (Ordóñez et al., 2003) show little variation in the area due to their natural origin. In contrast, $\mathrm{Zn}, \mathrm{Cd}, \mathrm{Hg}, \mathrm{Ag}$, Pb and $\mathrm{As}$ (in the 2011 sampling campaign), have high coefficients of variation and heterogeneous distribution, corresponding to anthropogenic origins. The concentrations of the latter elements in every square unit for the four sampling campaigns are shown in Fig. 3. The highest concentrations of these elements were found in the northern sampling square unit $(A)$, related to the raw materials used in the $\mathrm{Zn}$ metallurgical industry, located in the northern section of the city. The concentrations of some metals found in some sampling units were noticeably high. For example, elevated concentrations of $\mathrm{Zn} \mathrm{(4.6 \% ),} \mathrm{Pb}$ $(0.15 \%)$ or $\mathrm{Cd}$ (139 $\mathrm{mg} \mathrm{kg}^{-1}$ ) were found in unit A in 2011 . To the best knowledge of the authors, such values have not been exceeded in street dust in other cities in the world (Charlesworth et al., 2011).

Cluster Analysis (Fig. 4) revealed several groups of highly correlated elements, suggesting common origins. There was a distinct separation
Table 2

Reduction (\%) of concentrations of pollutants in the Avilés street dusts compared with trends across Europe, according to Harmens et al. (2013).

\begin{tabular}{|c|c|c|c|c|c|}
\hline \multirow[t]{2}{*}{ Element } & Europe $^{\mathrm{a}}$ & Avilés & Europe $^{a}$ & Avilés & Avilés net change \\
\hline & $1990-2005$ & $1996-2006$ & $2005-2010$ & $2006-2011$ & 1996-2011 \\
\hline $\mathrm{Al}$ & na & -28 & -28 & 35 & -2 \\
\hline As & -26 & 21 & -25 & 70 & 107 \\
\hline $\mathrm{Cd}$ & -51 & -51 & -7 & 193 & 45 \\
\hline $\mathrm{Cr}$ & -43 & 19 & -23 & 115 & 157 \\
\hline $\mathrm{Cu}$ & -11 & 4 & -6 & 75 & 82 \\
\hline $\mathrm{Fe}$ & -52 & -42 & -15 & 54 & -10 \\
\hline $\mathrm{Hg}$ & -23 & -82 & -20 & 388 & -14 \\
\hline $\mathrm{Ni}$ & -33 & -25 & -12 & 99 & 50 \\
\hline $\mathrm{Pb}$ & -77 & -48 & -36 & 72 & -11 \\
\hline V & -57 & -18 & -27 & 91 & 57 \\
\hline $\mathrm{Zn}$ & -34 & -73 & -7 & 557 & 74 \\
\hline
\end{tabular}

between elements with a clear anthropogenic origin (first cluster) and those with a natural or mixed origin (second cluster). The first subgroup of elements ( $\mathrm{Hg}, \mathrm{Zn}, \mathrm{Pb}, \mathrm{Tl}, \mathrm{Cu}, \mathrm{S}, \mathrm{Cd}, \mathrm{Ag}, \mathrm{As}$ and $\mathrm{Sb}$ ) within the first cluster can be linked to the $\mathrm{Zn}$ processing industry, which uses sphalerite ( $\mathrm{ZnS}$ ) as a raw material, in which $\mathrm{Fe}, \mathrm{Cd}$ and $\mathrm{Pb}$ are frequently found and less so $\mathrm{Mn}, \mathrm{Hg}$, In, Tl, Ga, Ge, Sb, Sn, $\mathrm{Ag}, \mathrm{Ba}, \mathrm{Au}, \mathrm{Bi}$ and $\mathrm{Cu}$

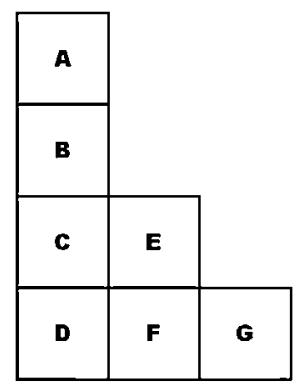

A)
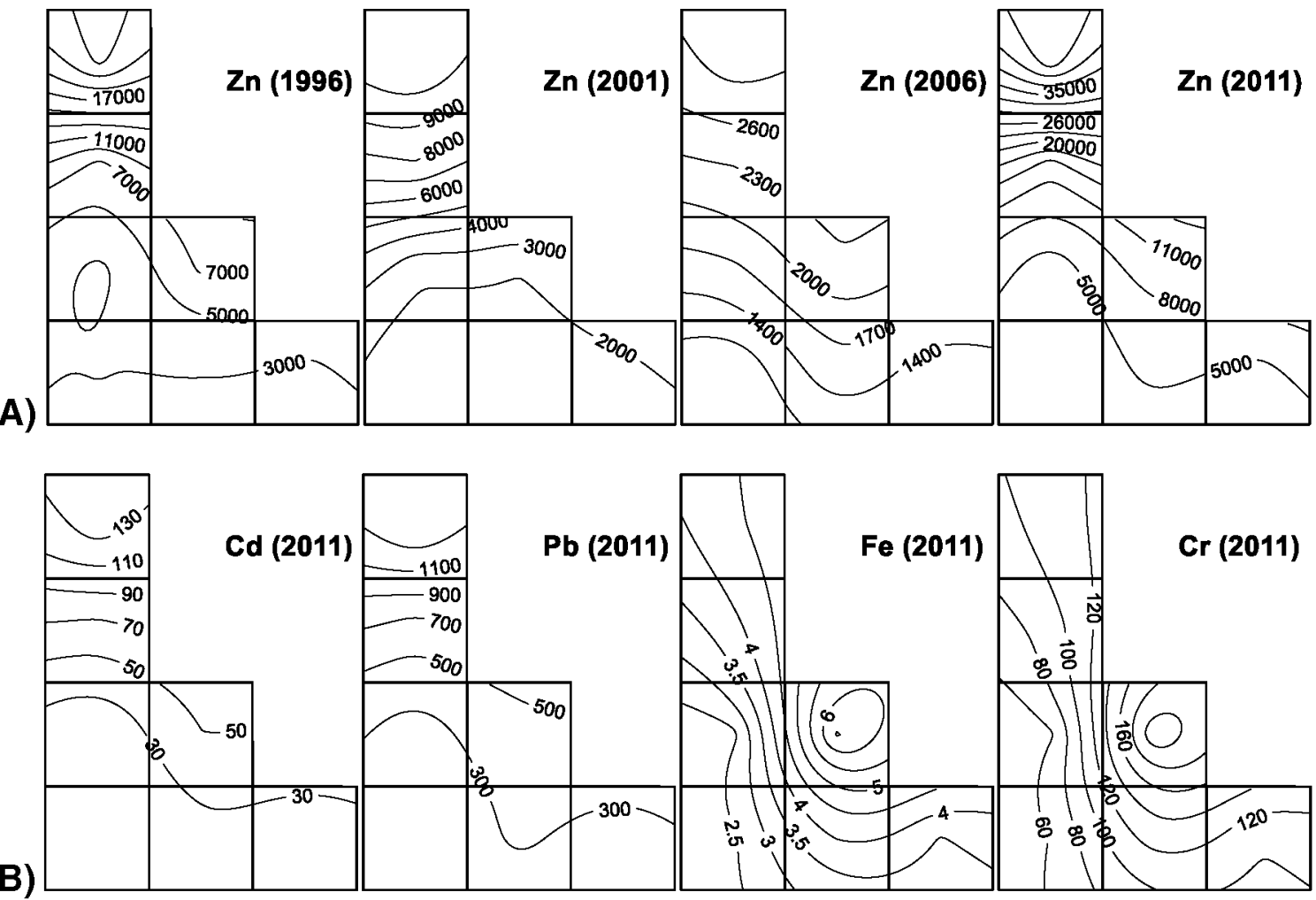

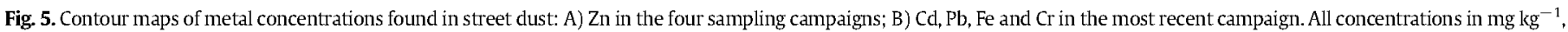
except Fe (in \%). 
Table 3

Urban environmental entropy calculated in terms of metal content in street dust of the 7 sampling units between 1996 and 2011, according to the methodology defined by Wang et al. (2012)

\begin{tabular}{lrrrrrr}
\hline Sampling unit & \multicolumn{1}{l}{$\mathrm{Al}$} & $\mathrm{Ba}$ & $\mathrm{Fe}$ & $\mathrm{Pb}$ & \multicolumn{1}{l}{$\mathrm{Zn}$} & \multicolumn{1}{l}{ Total } \\
\hline $\mathrm{A}$ & -0.007 & -0.001 & -0.054 & 0.009 & 0.318 & 0.130 \\
$\mathrm{~B}$ & 0.020 & -0.002 & -0.170 & 0.002 & 0.122 & -0.017 \\
$\mathrm{C}$ & 0.034 & 0.001 & -0.447 & -0.006 & 0.017 & -0.192 \\
$\mathrm{D}$ & 0.006 & 0.001 & -0.081 & -0.002 & -0.001 & -0.037 \\
$\mathrm{E}$ & -0.150 & 0.001 & 0.820 & -0.053 & 0.251 & 0.485 \\
$\mathrm{~F}$ & -0.004 & 0.007 & 0.148 & -0.001 & 0.051 & 0.092 \\
$\mathrm{G}$ & -0.026 & -0.001 & -0.044 & -0.001 & 0.021 & -0.011 \\
\hline
\end{tabular}

(Mindat, 2014). Anju and Banerjee (2011) found high, correlated concentrations of heavy metals including $\mathrm{Pb}, \mathrm{Zn}, \mathrm{Mn}$, and $\mathrm{Cd}$ in the soils surrounding historical $\mathrm{Pb}-\mathrm{Zn}$ mining and smelting areas in India, and $\mathrm{Xu}$ et al. (2013) found high As contents in the street dust of a $\mathrm{Zn}$ smelting district in China.

Another subgroup in the first cluster was composed of $\mathrm{Co}, \mathrm{Ga}, \mathrm{P}, \mathrm{Al}$ and Sc. These are related to aluminium processing by the Bayer process, using bauxite as the raw material. The main impurities in bauxite are $\mathrm{SiO}_{2}$, Fe, Ti, Be, Ca, Cr, Ga, Mn, V, P, K, S, Na, B, Ba, Cd, Co, Pb and Sc, depending on the initial composition of the ore and also processing conditions. Most bauxites contain between $0.001-0.05 \%$ of $\mathrm{Ga}_{2} \mathrm{O}_{3}$, and are the main source of $\mathrm{Ga}$ (RACI, 2011). Ga and Al are in the same column of the periodic table and therefore have similar chemical properties, reflected in their similar distribution in the present study. The second main cluster included the alkali elements $\mathrm{Na}-\mathrm{K}$ and $\mathrm{Ca}-\mathrm{Sr}$, whose origins are basically geogenic/natural. Fe, Ti, $\mathrm{Cr}, \mathrm{V}, \mathrm{Mn}$ and $\mathrm{Mg}$, most likely have mixed origins, i.e. natural and related to steel production and processing in coke ovens. The emissions from such facilities can be very broad, including organic compounds, as well as $\mathrm{As}, \mathrm{Cd}, \mathrm{Be}, \mathrm{Cr}, \mathrm{Pb}, \mathrm{Ni}$, Mn, Hg, Se, V, Cu and Zn (Graham and Holtgrave, 1990). Trace elements found in the coke are directly related to those present in raw coal and are highly variable, depending on its origin. The steel industry in the study area recently measured atmospheric annual emissions consistently above $60 \mathrm{~kg} \mathrm{As}, \mathrm{Hg}$ and $\mathrm{Cd}, 160 \mathrm{~kg} \mathrm{Cr}, 500 \mathrm{~kg} \mathrm{Cu}, 190 \mathrm{~kg} \mathrm{Ni}, 2$ t $\mathrm{Pb}, 580 \mathrm{~kg} \mathrm{Zn}$ and $88 \mathrm{t}$ of $\mathrm{PM}_{10}$ (MAGRAMA, 2014).
Sampling grids A and B, located to the north of the study area were clearly different from the rest, with a higher industrial influence, and higher concentrations of $\mathrm{Zn}, \mathrm{Cd}$ and $\mathrm{Hg}$. Some of the metals discussed here can have typically urban origins such as traffic or heating emissions, construction, and urban degradation of metal surfaces (Charlesworth et al., 2011). However, in this case, the industrial influence is so prevalent that its contribution masks any other potential sources.

Fig. 5A shows contour maps of $\mathrm{Zn}$ concentrations found in the four sampling campaigns; although the range was variable, the spatial distribution of this element was similar in the four maps; it tended to steadily increase in a northerly direction. The spatial distributions of $\mathrm{Cd}$ and $\mathrm{Pb}$ are shown in Fig. 5B and have the same tendency of increasing concentration towards the site where the $\mathrm{Zn}$ smelter is located. In contrast, elements such as Fe and $\mathrm{Cr}$ (Fig. 5B) showed a different distribution, with maximum contents in square $\mathrm{E}$, close to the steel industry.

Over time, the concentrations of $\mathrm{Zn}, \mathrm{Cd}, \mathrm{Hg}, \mathrm{Ag}$ and $\mathrm{As}$ in street dust decreased from 1996 to 2001, then either remained stable or further decreased from 2001 to 2006, and then rose to maximum values in 2011. These reductions in concentrations between the first and second sampling campaigns are in agreement with the European trend found in the study carried out by Harmens et al. (2013), leaving methodological differences aside (Table 2). In the case of Avilés, they can be related to changes in the method of transport of the $\mathrm{Zn}$ ore from the harbour to the factory which occurred in 1998. A covered conveyor belt replaced the lorries previously used to transport the dusty ore by road, moving the ore directly from the harbour to the factory, potentially reducing the release of particulate material and thus its incorporation in the street dust. A second important factor was that in 2004 the Spanish mine supplying the mineral to the $\mathrm{Zn}$ smelter closed, and the ore had to be imported, principally from Canada and Alaska. Due to climatic conditions in these countries, mines are only able to open half of the year, so the mineral is delivered to the $\mathrm{N}$ of Avilés in summer and autumn. It is then stored in uncovered heaps and there is great potential for it to be incorporated in street dust. For the rest of the year (winter and spring), mineral particles will only make a significant contribution to the trace element load of street dust if they are resuspended from the heaps by NW winds which are infrequent during these months. This fact would explain the increased concentrations of elements associated with the
A)

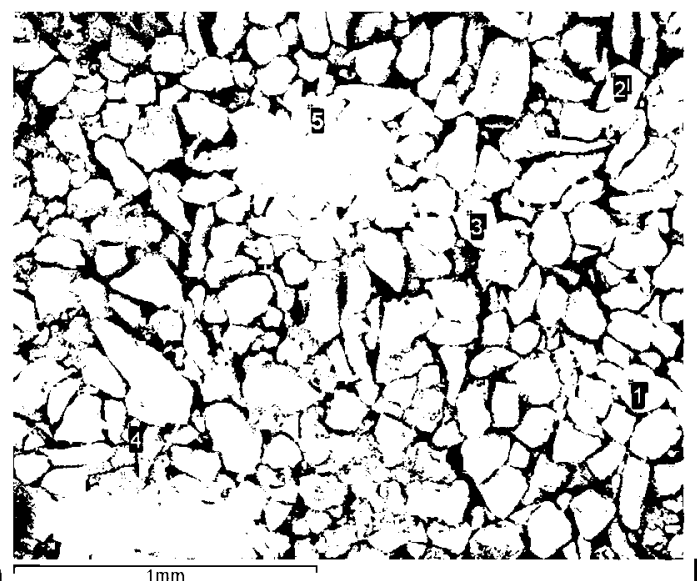

B)

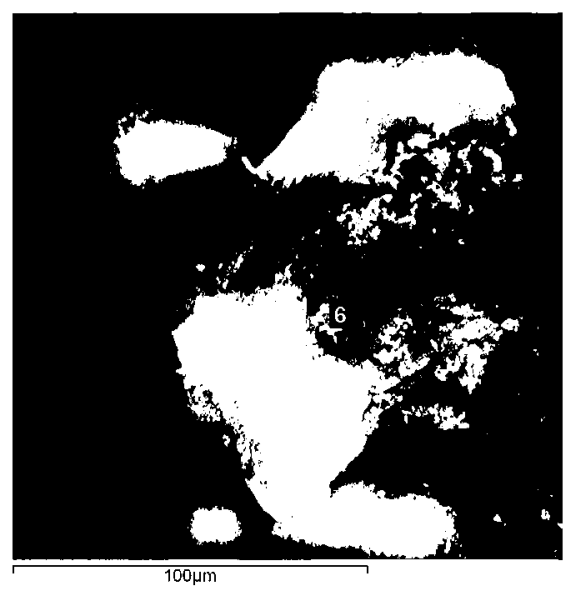

\begin{tabular}{c|ccccccccccc} 
Point & C & O & Al & Si & S & Ca & Mn & Fe & Zn & Pb & Hg \\
\hline $\mathbf{1}$ & & & & & 22.3 & & & & 77.7 & & \\
$\mathbf{2}$ & 24.2 & 30.0 & 1.6 & 6.1 & & 0.8 & & 2.78 & 28.5 & 6.1 & \\
$\mathbf{3}$ & 23.9 & 30.3 & 1.0 & 1.6 & & 2.9 & & 40.3 & & & \\
$\mathbf{4}$ & 27.0 & 18.0 & & 1.0 & 0.54 & 0.5 & & 0.90 & 52.1 & & \\
$\mathbf{5}$ & 17.3 & 35.1 & 2.2 & 2.2 & & 0.8 & & 42.4 & & & \\
$\mathbf{6}$ & 22.5 & 25.8 & & 0.8 & 6.02 & 2.1 & 0.87 & & 1.72 & & 40.2
\end{tabular}


Table 4

Descriptive statistics of the results for urban soils in the four sampling campaigns ( $\mathrm{n}=17$, same sample locations in all four campaigns).

\begin{tabular}{|c|c|c|c|c|c|c|c|c|c|c|c|c|c|c|c|c|c|c|c|c|c|c|c|c|c|}
\hline & \multicolumn{5}{|l|}{ Min. } & \multicolumn{5}{|l|}{ Max. } & \multicolumn{5}{|c|}{ Arith. mean } & \multicolumn{5}{|l|}{ Median } & \multicolumn{5}{|c|}{ Coef. variation } \\
\hline & 1996 & 2001 & 2006 & 2011 & & 1996 & 2001 & 2006 & 2011 & & 1996 & 2001 & 2006 & 2011 & & 1996 & 2001 & 2006 & 2011 & & 1996 & 2001 & 2006 & 2011 & \\
\hline $\begin{array}{l}\text { Sampling } \\
\text { depth (m) }\end{array}$ & 0.15 & 0.25 & 0.15 & 0.15 & 0.25 & 0.15 & 0.25 & 0.15 & 0.15 & 0.25 & 0.15 & 0.25 & 0.15 & 0.15 & 0.25 & 0.15 & 0.25 & 0.15 & 0.15 & 0.25 & 0.15 & 0.25 & 0.15 & 0.15 & 0.25 \\
\hline $\mathrm{Ag}\left(\mathrm{mg} \mathrm{kg}{ }^{-1}\right)$ & $<0.3$ & 0.10 & 0.20 & $<0.1$ & $<0.1$ & 1.20 & 0.50 & 1.30 & 1.90 & 0.60 & 0.69 & 0.19 & 0.62 & 0.72 & 0.22 & 0.7 & 0.1 & 0.5 & 0.55 & 0.2 & 0.41 & 0.65 & 0.52 & 0.84 & 0.62 \\
\hline $\mathrm{Al}(\%)$ & 0.60 & 0.59 & 0.76 & 0.69 & 0.73 & 2.49 & 1.67 & 1.58 & 2.95 & 2.31 & 1.55 & 1.19 & 1.14 & 1.39 & 1.53 & 1.52 & 1.18 & 1.2 & 1.26 & 1.51 & 0.36 & 0.30 & 0.20 & 0.40 & 0.32 \\
\hline As $\left(\mathrm{mg} \mathrm{kg}^{-1}\right)$ & 8.00 & 6.40 & 5.30 & 7.70 & 9.00 & 117 & 39.0 & 30.7 & 39.8 & 61.1 & 30.8 & 16.3 & 15 & 19.3 & 24.3 & 19 & 14.1 & 12.8 & 16.8 & 23.4 & 0.96 & 0.51 & 0.44 & 0.43 & 0.54 \\
\hline $\mathrm{Ba}\left(\mathrm{mg} \mathrm{kg}^{-1}\right)$ & 77.0 & 67.0 & 40.0 & 88.0 & 70.0 & 401 & 399 & 550 & 921 & 674 & 185 & 201 & 199 & 321 & 249 & 177 & 153 & 161 & 220 & 223 & 0.45 & 0.55 & 0.67 & 0.72 & 0.68 \\
\hline $\mathrm{Ca}(\%)$ & 0.24 & 0.19 & 0.21 & 0.23 & 0.24 & 10.9 & 8.46 & 13.5 & 9.48 & 6.56 & 1.69 & 1.36 & 2.35 & 4.12 & 2.06 & 0.64 & 0.58 & 1.56 & 3.25 & 1.13 & 1.64 & 1.43 & 1.33 & 0.75 & 1.09 \\
\hline $\mathrm{Cd}\left(\mathrm{mg} \mathrm{kg}{ }^{-1}\right)$ & 0.80 & 0.20 & 0.40 & 1.10 & 0.30 & 7.30 & 6.20 & 15.6 & 28.6 & 6.20 & 2.53 & 1.58 & 3.79 & 7.84 & 1.32 & 2.1 & 1.2 & 2.1 & 2.8 & 0.8 & 0.67 & 0.90 & 1.14 & 1.13 & 1.10 \\
\hline $\mathrm{Co}\left(\mathrm{mg} \mathrm{kg}^{-1}\right)$ & 2.00 & 1.90 & 1.90 & 0.90 & 2.60 & 30.0 & 10.2 & 10.4 & 11.4 & 14.1 & 9.59 & 5.36 & 5.45 & 7.28 & 7.04 & 8 & 5.5 & 5.1 & 7 & 6.7 & 0.78 & 0.39 & 0.41 & 0.39 & 0.46 \\
\hline $\mathrm{Cr}\left(\mathrm{mg} \mathrm{kg}^{-1}\right)$ & 9.00 & 9.70 & 11.0 & 12.0 & 12.0 & 40.0 & 107 & 91.0 & 75.0 & 38 & 22.5 & 23 & 24.5 & 32.8 & 20.9 & 21 & 17 & 20 & 27 & 22 & 0.37 & 0.97 & 0.76 & 0.47 & 0.32 \\
\hline $\mathrm{Cu}\left(\mathrm{mg} \mathrm{kg} \mathrm{kg}^{-1}\right)$ & 21.0 & 13.0 & 9.20 & 8.00 & 10.5 & 243 & 67.0 & 138 & 435 & 89.1 & 70.9 & 30.9 & 45.5 & 95.5 & 28.9 & 46 & 26.7 & 29.8 & 53.3 & 23.2 & 0.84 & 0.55 & 0.74 & 1.10 & 0.71 \\
\hline $\mathrm{Fe}(\%)$ & 1.80 & 1.32 & 1.40 & $1.4 \mathrm{c}$ & 1.47 & 9.83 & 9.89 & 7.35 & 6.77 & 4.18 & 4.03 & 2.62 & 2.6 & 2.92 & 2.58 & 3.23 & 1.91 & 2.28 & 2.62 & 2.6 & 0.57 & 0.77 & 0.53 & 0.45 & 0.29 \\
\hline $\mathrm{Ga}\left(\mathrm{mg} \mathrm{kg}^{-1}\right)$ & & 2.00 & 2.00 & 2.00 & 2.00 & & 5.00 & 4.00 & 8.00 & 7.00 & & 4.00 & 3.53 & 4.59 & 4.53 & & 4.00 & 4.00 & 5.00 & 5.00 & & 0.25 & 0.18 & 0.31 & 0.31 \\
\hline $\mathrm{Hg}\left(\mathrm{mg} \mathrm{kg}^{-1}\right)$ & 0.21 & 0.06 & 0.07 & 0.24 & 0.25 & 2.18 & 1.32 & 3.62 & 3.02 & 1.40 & 0.72 & 0.42 & 0.62 & 0.92 & 0.74 & 0.51 & 0.28 & 0.39 & 0.74 & 0.68 & 0.79 & 0.76 & 1.33 & 0.87 & 0.50 \\
\hline $\mathrm{K}(\%)$ & 0.07 & 0.07 & 0.08 & 0.07 & 0.07 & 0.42 & 0.34 & 0.29 & 0.49 & 0.57 & 0.21 & 0.16 & 0.17 & 0.2 & 0.19 & 0.19 & 0.13 & 0.17 & 0.17 & 0.15 & 0.53 & 0.52 & 0.35 & 0.50 & 0.66 \\
\hline $\mathrm{La}\left(\mathrm{mg} \mathrm{kg}^{-1}\right)$ & 8.00 & 6.00 & 8.00 & 7.00 & 9.00 & 36.0 & 16.0 & 19.0 & 21.0 & 26.0 & 16.8 & 11.9 & 11.2 & 12.4 & 14.9 & 16.0 & 13.0 & 11.0 & 13.0 & 14.0 & 0.40 & 0.24 & 0.25 & 0.28 & 0.29 \\
\hline $\mathrm{Mg}(\%)$ & 0.09 & 0.11 & 0.14 & 0.05 & 0.12 & 3.53 & 1.55 & 1.53 & 2.93 & 2.57 & 0.6 & 0.53 & 0.6 & 0.9 & 0.85 & 0.34 & 0.4 & 0.48 & 0.62 & 0.54 & 1.32 & 0.78 & 0.63 & 0.85 & 0.84 \\
\hline $\operatorname{Mn}\left(\mathrm{mg} \mathrm{kg}^{-1}\right)$ & 246 & 191 & 148 & 53.0 & 112 & 4261 & 6821 & 2388 & 2257 & 3099 & 1190 & 822 & 721 & 958 & 658 & 601 & 405 & 492 & 745 & 493 & 1.08 & 1.90 & 0.90 & 0.68 & 1.02 \\
\hline $\operatorname{Mo}\left(\mathrm{mg} \mathrm{kg}{ }^{-1}\right)$ & $<0.1$ & 0.40 & 0.20 & 0.60 & 0.30 & 3.00 & 3.90 & 1.80 & 6.10 & 2.10 & 1.43 & 1.12 & 0.92 & 1.89 & 0.84 & 1 & 0.7 & 0.8 & 1.4 & 0.6 & 0.60 & 0.91 & 0.43 & 0.74 & 0.64 \\
\hline $\mathrm{Na}(\%)$ & 0.01 & 0.004 & 0.008 & 0.007 & 0.003 & 0.04 & 0.06 & 0.04 & 0.04 & 0.05 & 0.01 & 0.01 & 0.01 & 0.02 & 0.01 & 0.01 & 0.01 & 0.01 & 0.01 & 0.01 & 0.58 & 1.03 & 0.46 & 0.47 & 1.14 \\
\hline $\mathrm{Ni}\left(\mathrm{mg} \mathrm{kg}^{-1}\right)$ & 5.00 & 4.70 & 5.60 & 4.30 & 5.70 & 35.0 & 27.6 & 21.7 & 31.7 & 23.8 & 16.9 & 13.4 & 12.9 & 17.9 & 15.8 & 15 & 11.8 & 12.4 & 16.4 & 16.7 & 0.53 & 0.48 & 0.33 & 0.38 & 0.35 \\
\hline$P(\%)$ & 0.04 & 0.03 & 0.02 & 0.05 & & 0.20 & 0.22 & 0.21 & 0.62 & 0.10 & 0.07 & 0.07 & 0.09 & 0.22 & 0.05 & 0.06 & 0.06 & 0.09 & 0.17 & 0.05 & 0.60 & 0.60 & 0.58 & 0.75 & 0.39 \\
\hline $\mathrm{Pb}\left(\mathrm{mg} \mathrm{kg}^{-1}\right)$ & 54.0 & 46.1 & 23.0 & 37.2 & 27.6 & 353 & 259 & 793 & 462 & 471 & 154 & 107 & 194 & 181 & 114 & 155 & 79.3 & 125 & 141 & 74.1 & 0.54 & 0.65 & 0.95 & 0.69 & 1.00 \\
\hline $\mathrm{Sb}\left(\mathrm{mg} \mathrm{kg}^{-1}\right)$ & $<1$ & 1.10 & 1.70 & 0.80 & & 15.0 & 6.10 & 4.90 & 8.70 & 2.30 & 6.6 & 2.67 & 3.07 & 3.48 & 1.11 & 6 & 2.5 & 2.6 & 2.7 & 0.8 & 0.67 & 0.49 & 0.38 & 0.66 & 0.63 \\
\hline $\operatorname{Sr}\left(\mathrm{mg} \mathrm{kg}^{-1}\right)$ & 10.0 & 9.00 & 11.0 & 14.0 & 8.00 & 381 & 200 & 204 & 230 & 115 & 45.6 & 36.8 & 56.6 & 106 & 45.2 & 24 & 19 & 37 & 98 & 28 & 1.92 & 1.24 & 0.86 & 0.65 & 0.77 \\
\hline $\operatorname{Th}\left(\mathrm{mg} \mathrm{kg}^{-1}\right)$ & $<1$ & 1.60 & 1.40 & 0.20 & 2.00 & 7.00 & 4.20 & 6.70 & 4.90 & 7.80 & 5.08 & 3.18 & 2.68 & 1.66 & 3.52 & 5 & 3.5 & 2.6 & 1.1 & 3.3 & 0.31 & 0.24 & 0.45 & 0.78 & 0.45 \\
\hline $\operatorname{Ti}(\%)$ & 0.01 & 0.002 & 0.004 & 0.002 & 0.002 & 0.02 & 0.05 & 0.02 & 0.03 & 0.01 & 0.01 & 0.008 & 0.009 & 0.009 & 0.004 & 0.01 & 0.005 & 0.006 & 0.007 & 0.004 & 0.25 & 1.50 & 0.70 & 0.67 & 0.55 \\
\hline$V(\mathrm{mg} \mathrm{k}$ & 22.0 & 13.0 & 19.0 & 20.0 & 19.0 & 55.0 & 92.0 & 43.0 & 54.0 & 45.0 & 34.8 & 27.0 & 27.3 & 33.2 & 28.4 & 32 & 22.0 & 25 & 32 & 29 & 0.28 & 0.66 & 0.25 & 0.25 & 0.26 \\
\hline $\mathrm{W}(\mathrm{mg} \mathrm{k}$ & $<0.1$ & $<0.1$ & 0.10 & $<0.1$ & $<0.1$ & $<0.1$ & 1.20 & 0.60 & 0.80 & 0.20 & $<0.1$ & 0.44 & 0.18 & 0.36 & 0.13 & $<0.1$ & 0.3 & 0.1 & 0.3 & 0.1 & & 0.83 & 0.73 & 0.52 & 0.43 \\
\hline $\mathrm{Zn}(\mathrm{mg} \mathrm{kg}-1)$ & 110 & 95.0 & 85.0 & 148 & 86.0 & 1024 & 1528 & 1599 & 5458 & 636 & 412 & 376 & 604 & 1545 & 249 & 356 & 238 & 478 & 848 & 218 & 0.68 & 0.95 & 0.72 & 1.07 & 0.58 \\
\hline
\end{tabular}


$\mathrm{Zn}$ ore in the 2011 campaign (carried out in the summer) relative to the 2006 one (undertaken at the end of the year). The change of origin - and composition - of the ore in 2004 is most likely also the explanation of the higher concentrations of $\mathrm{Ag}$ and $\mathrm{As}$ in street dust after that date (although the latter can be also related to the steel industry).

In spite of its increase in concentration in the northern grids in 2011 , $\mathrm{Pb}$ was generally lower in comparison with the first campaign. This is because not all of the $\mathrm{Pb}$ found in the street dust was necessarily associated with the $\mathrm{Zn}$ metallurgical industry since one major source of this element at the time that the first sampling was undertaken was traffic. This was highlighted by Ordóñez et al. (2003) due to the enrichment of $\mathrm{Pb}$ along busy roads, but the shift to unleaded petrol has since reduced the emissions of this metal. The concentration of $\mathrm{Ba}$, for example, usually linked to diesel vehicle emissions, has remained steady during monitoring. Concentrations of $\mathrm{Al}$ in street dust have not undergone substantial changes during this period. Despite the gradual substitution of coal for gas in the heating systems of the city, which could lead to a reduction of $\mathrm{Cu}$ concentration, the potential input of this metal from other sources such as coke production and traffic, has probably caused it to slightly increase.

The entropy results reinforce the geochemical discussion on temporal and spatial variability (Table 3 ). The total values of entropy are negative for four units (B, C, D and G) which implies that urbanization has not been negatively affected by the presence of metals in the street dust in these areas, in contrast to units $\mathrm{A}, \mathrm{E}$ and $\mathrm{F}$. The fact that the concentration of $\mathrm{Fe}$ and $\mathrm{Zn}$ increased in sampling units $\mathrm{E}$ and $\mathrm{A}$ respectively, is also reflected in an increase in urban entropy; this means a negative effect over these units, which is related to industrial emissions. By analysing the absolute value of entropy, urban activities over time have not significantly affected street dust Al content, although unit $\mathbf{E}$ has clearly improved in relation to this element. The same can be said for $\mathrm{Ba}$, as the entropy values are low for all the units; relating this metal to vehicular emissions, the central units (C, D, E and F, where most traffic concentrates) register less improvement (entropy $>0$ ), as traffic increases urban entropy in these neighbourhoods. In contrast, $\mathrm{Pb}$ emissions are now more related to industry (northern units: $\mathrm{A}$ and B) than traffic. It is noticeable that the entropy results for $Z n$ are negative in only one unit (D); this metal is the main input to the total entropy of the city.

Some examples of the SEM-EDAX analyses of street dusts are shown in Fig. 6 . In the sample from the $\mathrm{N}$ of the city, this shows that particles essentially contain $\mathrm{O}, \mathrm{C}, \mathrm{Fe}, \mathrm{Si}, \mathrm{Al}$ and $\mathrm{Ca}$ with concentrations of metals such as $\mathrm{Zn}, \mathrm{Pb}$ or $\mathrm{Hg}$ high enough to be detected in some of the particles. Particles of sulphides such as sphalerite and Zn carbonates were clearly identifiable in Fig. 6A, with an Hg-rich particle (probably cinnabar) in Fig. 6B. XRD analysis indicated quartz as the major crystalline mineral, and moderate quantities of calcite and sphalerite were also found.

\subsection{Soils}

The analytical results obtained for soils in the four sampling campaigns are summarised in Table 4 . As expected, the concentrations of anthropogenic trace elements, which are deposited on the surface of the soil as resuspended street dust and particulate atmospheric aerosol, decrease with depth. Concentrations of $\mathrm{Zn}, \mathrm{Cd}, \mathrm{Ag}, \mathrm{Pb}$ and $\mathrm{Ba}$ are 6.2, 5.9, 3.2, 1.6 and 1.3 times higher in the shallower samples.

Comparing campaigns with the same sampling depth, elements of anthropogenic origin generally increase with time in the soil. In 15 years, average contents of $\mathrm{Zn}, \mathrm{Cd}, \mathrm{Ba}$ and $\mathrm{Pb}$ have increased by $275 \%, 210 \%, 74 \%$ and $17 \%$, respectively. Contents of these elements have particularly increased to the $\mathrm{N}$ of the city, close to the $\mathrm{Zn}$ industry and the main routes of ore transport, and downwind from the industrial area. Thus, $Z n$ concentrations in sample nos. 5, 16 and 1 have increased 14,8 and 5 times, respectively in 15 years and concentrations of $\mathrm{Zn}$ and $\mathrm{Cd}$ in sample no. 16 reached values up to 5458 and $28.6 \mathrm{mg} \mathrm{kg}^{-1}$, respectively, in 2011, whereas samples taken in the residential southern area, such as nos. 10,11 or 12 had relatively little variation in concentration. However, elements such as Fe and Al, which have both industrial and natural origins, reflect the reduction in their industrial emissions over time, in decreased mean concentrations in superficial soils. A 65\% increase in $\mathbf{P}$ concentration over time is probably related to the fertilizer industry.

Compared to values in the surrounding street dust, average metal contents in soil are appreciably lower. Mean contents of $\mathrm{Zn}, \mathrm{Cd}, \mathrm{Ag}$ and $\mathrm{Pb}$ in the street dust sampled in 2011 were $7.8,5.8,5.2$ and 2.7 times higher than those found in superficial soils. Non-anthropogenic elements, such as $\mathrm{K}, \mathrm{Mg}$, Th or La, had similar or slightly higher average concentrations in soils and street dust, as the latter is fed from soil particle resuspension. In the most recent campaign, elements such as $\mathrm{Al}$ and $\mathrm{Ga}$ were lower in the street dust in comparison with the soils. This may again be due to the reduction in industrial emissions affecting dust, whereas soil acts as a pool that accumulates elements
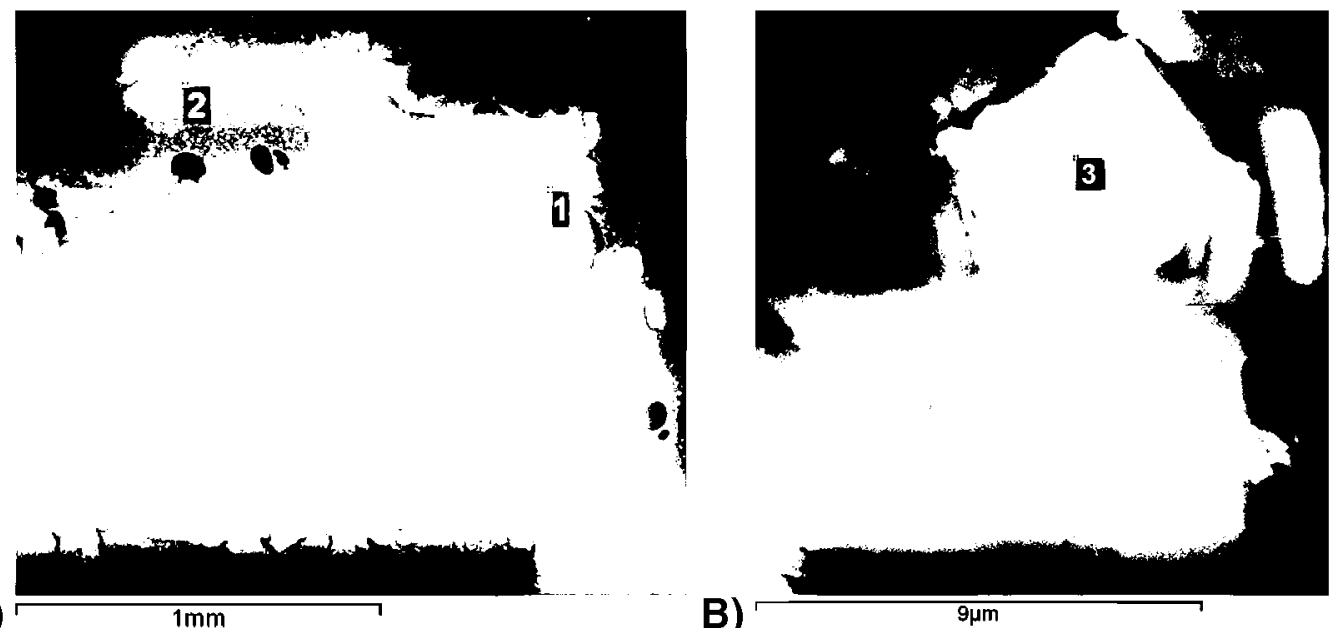

A)

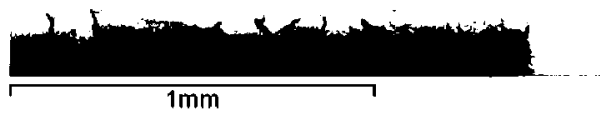

B)

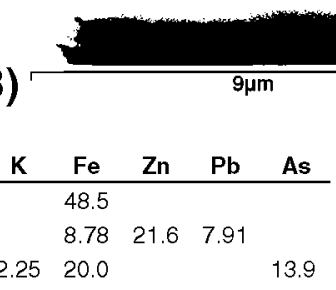

\begin{tabular}{c|ccccccccccc} 
Point & C & O & Al & Si & S & Ca & K & Fe & Zn & Pb & As \\
\hline $\mathbf{1}$ & 18.8 & 32.7 & & & & & & 48.5 & & & \\
$\mathbf{2}$ & 26.2 & 20.2 & & 2.4 & 11.6 & 1.31 & & 8.78 & 21.6 & 7.91 & \\
$\mathbf{3}$ & 10.4 & 48.8 & 1.9 & 1.8 & & & 2.25 & 20.0 & & & 13.9
\end{tabular}

Fig. 7. SEM-EDAX images and composition of analysed points in soil sample 16 (all results in wt\%). 
deposited over time; also, $\mathrm{Al}$ is present in the natural composition of soil (phyllosilicates). Despite these differences in absolute values, Cluster Analysis of the soil data essentially replicated the results previously found for street dust (Fig. 4): groupings reflecting elements related to typical emissions from $\mathrm{Zn}$ and Al metallurgy, the steel industry and those of natural origin.

Fig. 7 shows some images and analyses of soil sample 16 by SEMEDAX. The observed particles essentially comprised $\mathrm{O}, \mathrm{Si}, \mathrm{Al}, \mathrm{Fe}, \mathrm{Ca}$ and K; phyllosilicate sheets could also be clearly identified. In Fig. 7A, particles of $\mathrm{Fe}$ carbonate and weathered $\mathrm{Pb}$-rich sphalerite were observed and Fig. 7B shows Fe-As carbonate. According to XRD analysis, the soil sample contained quartz, muscovite and kaolinite as major mineral crystalline phases. Other metallic mineral phases could not be clearly distinguished by XRD analysis, since they were present in concentrations below $2 \%$. These techniques will be further explored in future research.

The soil was mostly sampled in parks and undeveloped land, not used to grow vegetables. The Regional Soil Guideline Levels for As, Cd, $\mathrm{Co}, \mathrm{Cu}, \mathrm{Mn}, \mathrm{Pb}$ and $\mathrm{Zn}$ defined in Asturias for residential soils $(40,20$, $25,400,2135,400$ and $4550 \mathrm{mg} \mathrm{kg}^{-1}$, respectively) were exceeded in a total of 26 of the samples, mostly in the most recent sampling campaign. In order to assess the potential adverse health effects of exposure to these trace elements, a risk assessment was carried out, using the results of the 2011 superficial sampling campaign. The output of the risk assessment (Table 5) indicated that the highest risk was associated with ingestion of soil particles and that the trace element of most concern was As. The exposure to As resulted in a cancer risk value for an adult individual of $2.6 \times 10^{-5}$, above the $1 \times 10^{-5}$ probability level deemed unacceptable by most regulatory agencies. Regarding noncancer effects, exposure to the urban soils yielded an aggregate hazard index (HI) below the threshold value of 1 . For children, $\mathrm{HI}>1$, with As and $\mathrm{Pb}$ as main contributors, and the value of cancer risk almost doubles.

Although the main conclusions of this risk assessment in terms of the elements and exposure pathways of main concern are perfectly valid, the quantitative results must be interpreted with caution because they are affected by three important sources of uncertainty: Firstly, the default exposure factors taken from the USEPA may not accurately reflect the characteristics and habits of the population in Avilés. In particular, contact rates and exposure frequency used in the model probably overestimate the actual values for Avilés, where climatic conditions restrict the amount of time spent outdoors, and the percentage of houses with gardens is lower than in the United States. Secondly, the use of the default Particulate Emission Factor suggested by the USEPA may not correctly extrapolate the concentration in air from the concentration in soil for the climatic conditions and surface soil characteristics of Avilés. Thirdly, the concentration term has been calculated using pseudo-total (i.e. aqua regia extractable) concentrations. For elements whose oral toxicity reference values have been derived from studies in which the hazardous element was administered in a soluble form (for example, As), the use of pseudo-total, instead of bioavailable, concentrations could lead to an over-estimate of risk. Elements present in the soil are bound to particles in a variety of ways, depending on which, the element will be released in the gastrointestinal tract to a lesser extent than that corresponding to the soluble form on which the toxicity value is based.

\section{Conclusions}

A geochemical study of street dust and urban soils of an industrial city was performed in four campaigns over a 15 year period. In both milieu, the industrial influence was clearly identified. Elements such as $\mathrm{Zn}, \mathrm{Cd}, \mathrm{Hg}, \mathrm{Ag}, \mathrm{Pb}$ or As were found in high concentrations (up to $4.6 \%$ and $0.5 \%$ of $\mathrm{Zn}$ in dust and soil, respectively), particularly in the $\mathrm{N}$ of the city. These elements appear to be correlated in their distribution and can be related to the $\mathrm{Zn}$ ore, sphalerite, and its associated trace 
elements, used in the $\mathrm{Zn}$ industry (particles of this sulphide were identified in soil and street dust by SEM-EDAX and XRD analyses). The spatial and temporal distributions of these elements are a function of the distance to the storage area of the ore, the intensity and method of transport from the port, and the prevailing wind direction. The elemental concentrations in the particulate matter, characterised by short residence times, show high variability depending on the time of the year that the sampling was done; they are more stable in the soils, as they retain the input of particles deposited over time. In both cases, the average concentrations of these elements have generally increased over the monitored period. In agreement with this, the entropy model used to analyse the relationship between the development of urbanization in the period 1996-2011 and the street dust geochemistry shows that urban development has been negatively affected by the presence of metals in the street dust, particularly in the north of the city, with $\mathrm{Fe}$ and particularly $\mathrm{Zn}$ the main metals responsible.

Other groups of elements included those related to bauxite and its impurities, used in the $\mathrm{Al}$ industry ( $\mathrm{Al}, \mathrm{Ga}$, etc.), those related to the steel industry ( $\mathrm{Fe}, \mathrm{Cr}, \mathrm{V}, \mathrm{Mn}$, etc.) or those with natural/geogenic origin, not linked to anthropogenic activity ( $\mathrm{La}, \mathrm{Th}, \mathrm{Ca}, \mathrm{Na}$, etc.). Many of the elements cannot be classified with certainty, as they have more than one possible industrial or urban source. In this case, typical urban geochemical fingerprints, such as traffic, are masked by the widespread and considerable industrial influence.

In comparison with temporal trends across Europe in general, it was found that until the present sampling campaign, concentrations of pollutants in the street dusts appeared to mainly decrease in common with European values. However, whilst European values continue in their downward trend, those from Avilés mainly increased in concentration, reflecting industrial activity in the area in spite of various actions having been taken to reduce its impact.

Metal reference values established for soils with the characteristics of those sampled were exceeded at times. Although the assumptions in the model may result in an overestimate of the quantitative results arrived at, a risk assessment applied to the urban soils reveals that the concentrations of some elements, such as $\mathrm{As}$ and $\mathrm{Pb}$, could result in unacceptable levels of risk for residential receptors, with ingestion of soil the exposure pathway with the largest contribution. However, samples with the highest concentrations were taken in industrial, rather than in residential areas. Some environmental measures, such as a new isolated warehouse and a new conveyor belt associated with the $\mathrm{Zn}$ industry, which will come into use shortly, will reduce particle emissions associated with ore transport and storage, and should have positive environmental and human health benefits.

\section{Acknowledgements}

The authors thank the students R. García, J.M. Morán and E. Campa for their sampling and lab work.

\section{References}

Alloway, B.J., 1990. Heavy Metals in Soils. Blackie, London.

Anju, M., Banerjee, D.K., 2011. Associations of cadmium, zinc, and lead in soils from a lead and zinc mining area as studied by single and sequential extractions. Environ. Monit. Assess. 176, 67-85.

Cabral, P., Augusto, G., Tewolde, M., Araya, Y., 2013. Entropy in urban systems (review). Entropy $15,5223-5236$.

Charlesworth, S., Everett, M., McCarthy, R., Ordóñez, A., De Miguel, E., 2003. A comparative study of heavy metal concentration and distribution in deposited street dusts in a large and a small urban area: Birmingham and Coventry, West Midlands, UK. Environ. Int. 29, 563-573.

Charlesworth, S., De Miguel, E., Ordóñez, A., 2011. A review of the distribution of particulate trace elements in urban terrestrial environments and its application to considerations of risk. Environ. Geochem. Health 33 (2), 103-123.

De Miguel, E., Llamas, J.F., Chacon, E., Berg, T., Larssen, S., Royset, O., Vadset, M., 1997. Origin and patterns of distribution of trace elements in street dusts; unleaded petrol and urban lead. Atmos. Environ. 31 (17), 2733-2740.

De Miguel, E., Iribarren, I., Chacón, E., Ordóñez, A., Charlesworth, S., 2007. Risk-based evaluation of the exposure of children to trace elements in playgrounds in Madrid (Spain). Chemosphere 66, 505-513.

Ferguson, J.E., Kim, N., 1991. Trace elements in street and house dusts source and speciation. Sci. Total Environ. 100, 125-150.

Gobierno del Principado de Asturias, 2014. Plan de mejora de la calidad del aire en la zona ES0302 Asturias Central. Consejería de Fomento, Ordenación del Territorio y Medio Ambiente, Asturias, Spain (428 pp.).

Graham, J.D., Holtgrave, D.R., 1990. Coke oven emissions: a case study of technologybased regulation. Report to the Congressional Research Service. Washington, DC; Reprinted in Risk. Health Saf. 1, 243-272.

Harmens, H., Norris, D., Mills, G., 2013. Heavy Metals and Nitrogen in Mosses: Spatial Patterns in 2010/2011 and Long-term Temporal Trends in Europe. Centre for Ecology \& Hydrology, UK

Kelly, J., Thornton, I., Simpson, P.R., 1996. Urban geochemistry: a study of influence of anthropogenic activity on heavy metal content of soils in traditionally industrial and non-industrial areas of Britain. Appl. Geochem. 11, 363-370.

Li, X., Liu, P.S., 2001. Heavy metal contamination of urban soils and street dusts in Hong Kong. Appl. Geochem. 16, 1361-1368.

López, J., Flor, G., 2008. Evolución ambiental del estuario de Avilés (1833-2006). Trab. Geol. 28, 119-135.

Loredo, J., Ordóñez, A., Charlesworth, S., De Miguel, E., 2003. Influence of industry on the geochemical urban environment of Mieres (Spain) and associated health risk. Environ. Geochem. Health 25 (3), 307-323.

MAGRAMA (Ministerio de Agricultura, Alimentación y Medio Ambiente), 2014. http:// www.prtr-es.es/informes/fichacomplejo.aspx?id_complejo $=3143$.

Miler, M., Gosar, M., 2012. Characteristics and potential environmental influences of mine waste in the area of the closed Mezica $\mathrm{Pb}-\mathrm{Zn}$ mine (Slovenia). J. Geochem. Explor. $112,152-160$.

Miler, M., Gosar, M., 2013. Assessment of metal pollution sources by SEM/EDS analysis of solid particles in snow: a case study of Zerjav, Slovenia. Microsc. Microanal. 19 (6), 1606-1619.

Miler, M., Gosar, M., 2015. Chemical and morphological characteristics of solid metalbearing phases deposited in snow and stream sediment as indicators of their origin. Environ. Sci. Pollut. Res. Int. 22 (3), 1906-1918. http://dx.doi.org/10.1007/s11356014-3589-x.

Mindat, 2014. http://www.mindat.org.

Ordóñez, A., Loredo, J., De Miguel, E., Charlesworth, S., 2003. Distribution of heavy metals in the street dusts and soils of an industrial city in northern Spain. Arch. Environ. Contam. Toxicol. 44, 160-170.

Ouyang, T., Fu, S., Zhu, Z., Kuang, Y., Huang, N., Wu, Z., 2008. A new assessment method for urbanization environmental impact: urban environment entropy model and its application. Environ. Monit. Assess. 146, 433-439.

RACI (Royal Australian Chemical Institute), 2011. Gallium. www.raci.org.au/document/ item/429.

SADEI, 2014. Reseña Estadística de los Municipios Asturianos. http://www.sadei.es/es/ portal.do?IDM=20\&NM=2.

Sancini, A., Tomei, F., Capozzella, A., Pacchiarotti, A., De Sio, S., Tomei, G., Palermo, P., Ciarroca, M., 2011. Respiratory effects in the general population exposed to urban pollution. J. Environ. Prot. 2, 974-981.

Sezgin, N., Ozcan, H.K., Demir, G., Nemlioglu, S., Bayat, C., 2004. Determination of heavy metal concentrations in street dusts in Istanbul E-5 highway. Environ. Int. 29 (7), 979-985.

Tositti, L., Brattich, E., Masiol, M., Baldacci, D., Ceccato, D., Parmeggiani, S., Stracquadanio, M., Zappoli, S., 2014. Source apportionment of particulate matter in a large city of southeastern Po Valley (Bologna, Italy). Environ. Sci. Pollut. Res. 21, 872-890.

US DoE, 2014. RAIS (The Risk Assessment Information System). http://rais.ornl.gov.

US EPA, 2014. http:/www.epa.gov/osp/hstl/tsc/software.htm.

Visman J., De monsterneming van heterogene binomiale korrelmengsels, in het bijzonder steenkool, PhD Thesis, Technical University of Delft

Wang, Q., Yuan, X., Ma, C., Zhang, Z., Zuo, J., 2012. Research on the impact assessment of urbanization on air environment with urban environmental entropy model: a case study. Stoch. Env. Res. Risk A. 26, 443-450.

Xu, S., Zheng, N., Liu, J., Wang, Y., Chang, S., 2013. Geochemistry and health risk assessment of arsenic exposure to street dust in the zinc smelting district, Northeast China. Environ. Geochem. Health 35, 89-99.

Zierock, K.M., 1994. Technical note on best available technologies not entailing excessive costs for heavy metal emissions from non-ferrous industrial plants. European Commission Report, Brussels (153 pp.). 